\title{
COMPARISON OF NATURALLY PREPARED COAGULANTS FOR REMOVAL OF COD AND COLOR FROM TEXTILE WASTEWATER
}

\section{PATEL H.* VASHI R.T.}

Received: $16 / 10 / 12$

Accepted: 20/05/13

\author{
Department of Chemistry, Navyug Science College \\ Rander Road, Surat - 395009, Gujarat, India
}

\begin{abstract}
The wastewater generated by the textile industry is rated as the most polluting among all industrial sectors considering both volumes discharged and effluent composition. Present investigation intended for COD and color removal from textile wastewater using naturally prepared coagulants i.e. Surjana Seed Powder (SSP), Maize Seed Powder (MSP) and Chitosan. Effect of coagulant dose, flocculation time and temperature has been studied. The Sludge Volume Index (SVI) and turbidity were examined for various effects. SSP was more effective than Chitosan and MSP for the removal of COD and color and also, Chitosan was more efficient than SSP and MSP considering SVI and turbidity. Maximum percentage reduction corresponds to 75.6 and 62.8 was obtained for removal of COD and color respectively, using SSP.
\end{abstract}

KEYWORDS: Textile wastewater, Naturally prepared coagulants, COD, Color.

\section{INTRODUCTION}

In view of growing awareness of pollution problems, dispersal of organic contamination in the environment is becoming a matter of concern. Ever increasing use of chemical and related compounds in each and every field of industry and ever agriculture summons an urgent need of method for their effective removal from water and wastewater. Increased population and modernized civilization trend gave rise to blooming of textile sectors in India. An estimate shows that textiles account for $14 \%$ of India's industrial production and around $27 \%$ of its export earnings. India is the second largest producer of cotton yarn and silk and third largest producer of cotton and cellulose fiber. The total production of yarn during the year 2003-2004 was $3051 \mathrm{kt}$. There are about 10,000 garment manufacturers and 2100 bleaching and dyeing industries in India (Ranganathan et al., 2007). However, the textile industry is facing major problems in the disposal of wastewater generated from textile dye and finishing processes. Textile dye wastewater contains strong color, high Chemical Oxygen Demand (COD), high total dissolved solids and is also bio-refractory in nature. The mostly polluted and large amounts of wastewaters are generated from the dye-houses of the textile industry (Muthukumar et al., 2004).

Traditional methods for dealing with textile wastewater consist of various combinations of biological, physical and chemical methods. Biological treatment of dyeing wastewater is cheaper than other methods, but it is less efficient for decolorization due to toxicity of the wastewater and the need for an aeration system. Although the dyestuff and colored materials in wastewater can be effectively destroyed by advanced chemical oxidation such as $\mathrm{UV} / \mathrm{H}_{2} \mathrm{O}_{2}, \mathrm{O}_{3}$ and adsorption using activated carbon, the costs of these methods are relatively high for an economically feasible treatment of the textile wastewater (Kobya et al., 2006). The removal of particles and organic matter from wastewater is often achieved by coagulation, usually performed with iron or aluminum salts. Coagulation can be interpreted as the conversion of colloidal and dispersal particles into small visible floc upon addition of a simple electrolyte (coagulant). Increasing the concentration of the electrolyte results in a compression of the electrical double layer surrounding each suspended particle, a decrease in the magnitude of the repulsive interactions between particles and destabilization of the particles. The 
most common traditional coagulant used in wastewater treatment is alum, iron (III) salts and PAC (polyaluminum chloride), due to its effectiveness in treating a wide range of wastewater type and relatively low cost (Rahbar et al., 2006). But, recent studies have pointed out several drawbacks of using aluminum salts, such as Alzheimer's disease associated with residual aluminum in treated water and production of large sludge volumes. There is also the problem of reaction of aluminum with natural alkalinity present in the water leading to a reduction of $\mathrm{pH}$ and low efficiency of coagulation in cold waters. To ease the problems associated with chemical coagulants, several studies have pointed out the introduction of naturally prepared coagulants produced or extracted from microorganisms, animals, or plants (Vieira et al., 2010). Some naturally prepared coagulants for contamination removal were also investigated (Oladoja and Aliu, 2008; 2009).

Previously we successfully remove Congo Red dye from its aqueous solution using naturally prepared coagulants viz. SSP, MSP and Chitosan (Patel and Vashi, 2012). Present study was proposed to remove $\mathrm{COD}$ and color from real textile mill wastewater using naturally prepared coagulants viz SSP, MSP and Chitosan. The effect of various parameters like coagulant dose, flocculation time and temperature were investigated. The Sludge Volume Index (SVI) and turbidity were evaluated for various parameters.

\section{MATERIAL AND METHODS Surjana Seed Powder}

Surjana Seed is a seed of tropical plant of Moringa oleifera belonging to family of Moringaceae. Moringa oleifera is the most widespread species which grows quickly at low altitudes, generally used as vegetable, medicine and sources of vegetable oil. The Surjana is easily available in Indian region. The mature seed of plant seed was washed with water to remove dust and were dried in an oven at $60 \pm 2{ }^{\circ} \mathrm{C}$. The dried seed were crushed and powdered and sieved through $200 \mu \mathrm{m}$ nylon sieves and used as coagulant. Previously removal of dye, surfactant and other contaminations using Moringa oleifera seed was studied by some scientists (Beltran-Heredia and Martin, 2008; Bhatia et al., 2006; Kwaambwa et al., 2010). The chemical composition and other properties like active agent of seeds of Moringa oleifera Lam was demonstrated by Ndabigengesere et al. (1995) and Gassenschmidt et al. (1995).

\section{Maize Seed Powder}

Maize (scientific name: Zeemays) is commonly known as corn in some countries. The Maize seed is easily available in Indian region. The mature seed of plant seed was washed with water to remove dust and were dried in an oven at $60 \pm 2{ }^{\circ} \mathrm{C}$. The dried seed were crushed and powdered and sieved through $200 \mu \mathrm{m}$ nylon sieves and used as coagulant. Researchers had tried to utilize maize seed as coagulant/ coagulant aid (Raghuwanshi et al., 2002; Mandloi et al., 2004; Bhole, 1995).

\section{Chitosan}

Chitin is cellulose like biopolymer widely distributed in nature, especially in marine invertebrates, insects, fungi, and yeasts. Its deacetylation of chitin [poly- $\beta-(1 \rightarrow 4)-\mathrm{N}$-acetyl-Dglucosamine], is readily soluble in acidic solutions, which makes it more available for applications. Chitosan is a yellow colored powder, biodegradable, non-toxic, linear cationic polymer of high molecular weight with a variety of applications including water treatment, chromatography, additives for cosmetics, textile treatment for antimicrobial activity, novel fibers for textiles, photographic papers, biodegradable films, biomedical devices, improvement of quality and shelf-life of food and microcapsule implants for controlled release in drug delivery. Also, it is utilized for recovery of suspended solids in processing wastes from poultry, eggs, cheese and vegetable operations. It was procured from Sigma Aldrich, India. Many scientists were successfully utilized Chitosan as coagulant (Roussy et al., 2005; Szygla et al., 2009), adsorbent (Minamisawa et al., 2004; Gibbs et al., 2004) and with adsorbent (Huang and Chen, 1996).

\section{Experimental Design}

The textile wastewater samples were withdrawn from Pandesara, GIDC, Gujarat, India in sampling bottles and placed in ice box to preserve the characteristics of wastewater. The wastewater was analyzed as per standard method (APHA, 1992). For treatment of the wastewater samples, the required dosages of the coagulant was added to a small portion of the wastewater sample, stirred well and kept in contact for the requisite flocculation time and at the desired temperature under 
investigation and then filtered. Important physico-chemical characteristics viz. COD and color was determined before and after treatment.

To determine the effect of different amounts of naturally prepared coagulants like SSP, MSP and Chtiosan, the wastewater was treated with 5.0,10.0, 15, 20.0, 25.0 and $30.0 \mathrm{~g} \mathrm{~L}^{-1}$ of each coagulant for constant flocculation time $(120 \mathrm{~min})$ at constant temperature $(300 \mathrm{~K})$. The effect of flocculation time was studied by treating the wastewater with $20.0 \mathrm{~g} \mathrm{~L}^{-1}$ of SSP, MSP and Chtiosan at constant temperature $(300 \mathrm{~K})$ and for durations of 15 to 150 minutes at constant temperature $(300 \mathrm{~K})$. To determine the effect of temperature, the wastewater was treated with $20.0 \mathrm{~g} \mathrm{~L}^{-1}$ of SSP, MSP and Chtiosan for constant flocculation time $(120 \mathrm{~min})$ at various temperatures $(298,303,308,313, .318$, 323 and $328 \mathrm{~K}$ ). The neutral pH of system was maintained by $1.0 \mathrm{~N} \mathrm{HCl}$ or $1.0 \mathrm{~N} \mathrm{NaOH}$ during experiment. All other chemicals used were of analytical reagent grade.

Also, the characterization of sludge produced was measured in terms of Sludge Volume Index (SVI) and turbidity was determined using standard method for all process parameters.

\section{RESULTS AND DISCUSSION}

\section{Characterization of textile wastewater}

It was reported that water requirement vary from 61 to 646 liters per $\mathrm{kg}$ of cloth processed with an average value of 235 liters per $\mathrm{kg}$. These values correspond to 12 - 130 liter per meter of cloth with an average value of 47 liters per $\mathrm{kg}$. The $\mathrm{pH}$ of the investigated textile mill effluent ranges from 9.24 to 7.64 having average value of 8.2. The color of the wastewater is brownish yellow having color unit 291.3 Hazen. The average value of COD, BOD, Total Dissolved Solid (TDS), Hardness, Alkalinity, Fluoride, Chloride and Sulphate were 1556.2, 924.1, 7545.3, 1152.7, 780.7, 912.3, 395.3 and 788.1 $\mathrm{ppm}$ respectively. Also, average value of Electrical Conductivity was found to be $8145.2 \mu \mathrm{s} \mathrm{cm}^{-1}$. High value of contaminations are presented due to usage of wide range of chemicals such as starches, dextrin, gums, glucose, waxes, pectin, alcohol, fatty acids, acetic acid, soap, detergents, sodium hydroxide, carbonates, sulfides, sulfites, chlorides, dyes, pigments, carboxy methyl cellulose, gelatin, peroxides, silicones, flourcarbons, resins, etc. in wet processes of textile mill. Same types of contaminations were found, while investigating textile wastewater (Kuai et al., 1998; Bisschops and Spanjers, 2003).

\section{Effect of Coagulant Dose}

Coagulation dosage is one of the most important factors that have been considered to determine the optimum condition for the performance of coagulants in coagulation and flocculation. Essentially, insufficient dosage or overdosing would result in the poor performance in flocculation. Therefore, it is significant to determine the optimum dosage in order to minimize the dosing cost and sludge formation and also to obtain the optimum performance in treatment. The effect of coagulant doses, 5 to $35 \mathrm{~g} \mathrm{~L}^{-1}$ for the removal of COD and color from dyeing mill wastewater maintaining temperature of $300 \mathrm{~K}$ and flocculation time 60 min using Chitosan, SSP and MSP was shown in Table 1. It shows that there was continuous removal with increases in coagulant doses up to $30.0 \mathrm{~g} \mathrm{~L}^{-1}$, which may be due to increases of substantially. Natural seed have been found to act as coagulant because natural seeds are naturally occurring polyelectrolytes (bio colloids). In wastewater in act as polyvalent ions, this polymer chain carries a very large numbers of ionic sites along its length. Coagulation takes place by the neutralization of charges on the electronegative colloids particles by this ionized centre or by hydrogen among the charged surfaces. Electro static cross linkage also binds the linear chain together. The same/ lower removal value of COD and color after $30.0 \mathrm{~g} \mathrm{~L}^{-1}$ indicates that a optimum dose of $30.0 \mathrm{~g} \mathrm{~L}^{-1}$ was found for all coagulants investigated. The highest removal of COD and color was found to be 70.3 and $62.8 \%$ respectively using SSP. Further, highest removal of COD and color was found to be 68.8 and $47.0 \%$ respectively using MSP. Moreover, highest removal of COD and color was found to be 64.7 and $42.8 \%$ respectively using Chitosan. This may be as a result of resuspension of solids at this concentration. Furthermore, the high concentrations $\left(>30.0 \mathrm{~g} \mathrm{~L}^{-1}\right)$ of the coagulant may be confer positive charges on the particle surface (a positive zeta potential), thus redispersing the particles (Amuda et al., 2006). 
Table 1. Influence of different doses of SSP, MSP and Chitosan for removal COD and color from textile wastewater

\begin{tabular}{|c|c|c|c|c|c|c|}
\hline \multirow{3}{*}{$\begin{array}{c}\text { Coagulant } \\
\text { Dose } \\
\left(\mathrm{g} \mathrm{L}^{-1}\right) \\
\end{array}$} & \multicolumn{6}{|c|}{ Percentage Removal } \\
\hline & \multicolumn{2}{|c|}{ SSP } & \multicolumn{2}{|c|}{ MSP } & \multicolumn{2}{|c|}{ Chitosan } \\
\hline & COD & Color & COD & Color & COD & Color \\
\hline 5.0 & 26.62 & 9.99 & 20.73 & 8.00 & 13.24 & 5.14 \\
\hline 10.0 & 37.59 & 21.70 & 31.79 & 16.85 & 25.42 & 13.71 \\
\hline 15.0 & 48.53 & 37.12 & 50.54 & 24.27 & 40.09 & 19.99 \\
\hline 20.0 & 61.94 & 49.77 & 54.62 & 33.32 & 50.38 & 28.56 \\
\hline 25.0 & 74.11 & 58.51 & 62.53 & 44.49 & 56.43 & 38.49 \\
\hline 30.0 & 70.34 & 62.82 & 68.82 & 47.03 & 64.68 & 42.83 \\
\hline 35.0 & 69.42 & 58.54 & 67.73 & 45.69 & 63.53 & 42.83 \\
\hline
\end{tabular}

\section{Effect of Flocculation Time}

The time of macrofloc formation (flocculation time) is one of the operating parameters that is given great consideration in any water treatment plant that involves coagulation-flocculation operations. Figure 1 represents the effect of flocculation time for removal of COD and color using coagulants i.e. SSP, MSP and Chitosan maintaining temperature of $300 \mathrm{~K}$ and coagulant dosage of $20 \mathrm{~g} \mathrm{~L}^{-1}$. The consistence increment of removals was revealed with increasing flocculation time up to $120 \mathrm{~min}$, and thereafter percentage removal was decreased or no percentage removal was found. The optimum flocculation time was reached at $120 \mathrm{~min}$. The highest removal of COD and color was found to be 75.6 and $52.8 \%$ respectively using SSP. Further, highest removal of COD and color was found to be 74.7 and $48.9 \%$ respectively using MSP. Moreover, highest removal of COD and color was found to be 69.6 and $42.8 \%$ respectively using Chitosan. Such results of removals with increasing flocculation time were reported earlier (Ebeling et al., 2003; Omar et al., 2008; Fu and Yu, 2007).

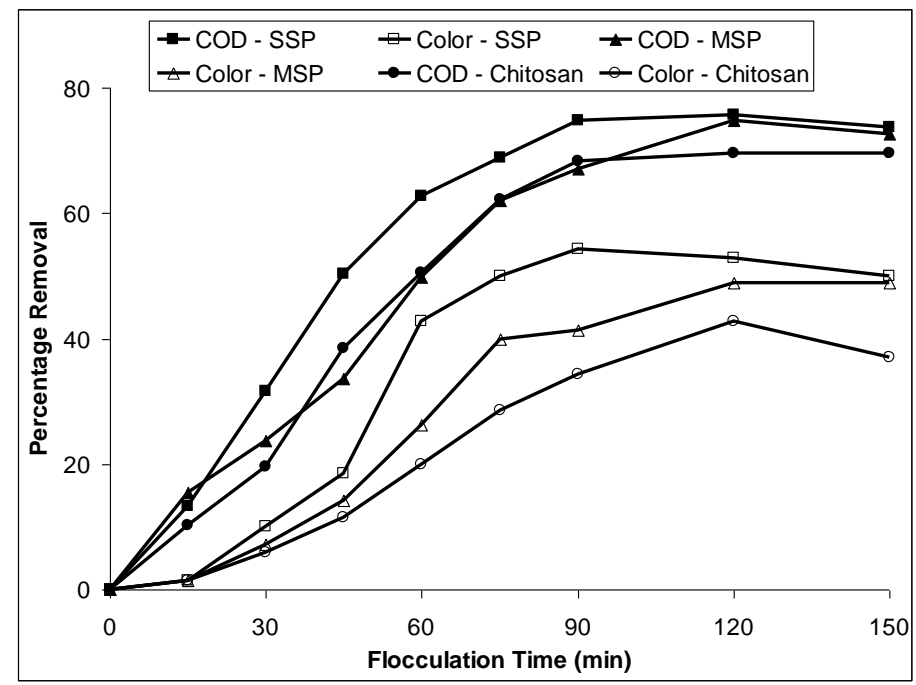

Figure 1. Effect of flocculation time for removal of COD and color from textile wastewater

\section{Effect of Temperature}

The effect of temperature on COD and color removal using Chitosan, SSP and MSP was investigated at 298, 303, 308, 313, 323 and $328 \mathrm{~K}$ and data were represented in Figure 2. The nature of curve shows that the percentage removal was continuously increasing with increasing temperature. A straight line was observed after $323 \mathrm{~K}$. So, optimum temperature was attained at $323 \mathrm{~K}$ for all coagulants. The highest removal of COD and color was found to be 74.9 and $67.1 \%$ respectively when SSP was used. Further, highest removal of COD and color was found to be 72.6 and $58.5 \%$ respectively when MSP was used. Moreover, highest removal of COD and color was found to be 69.6 and $47.3 \%$ respectively when Chitosan was used. At higher temperature, higher percentage removals were achieved may be due to better floc settlement when the temperature 
increases. Such types of removal pattern were found by various investigators (Jiang and Graham, 1996; Rios et al., 1998).

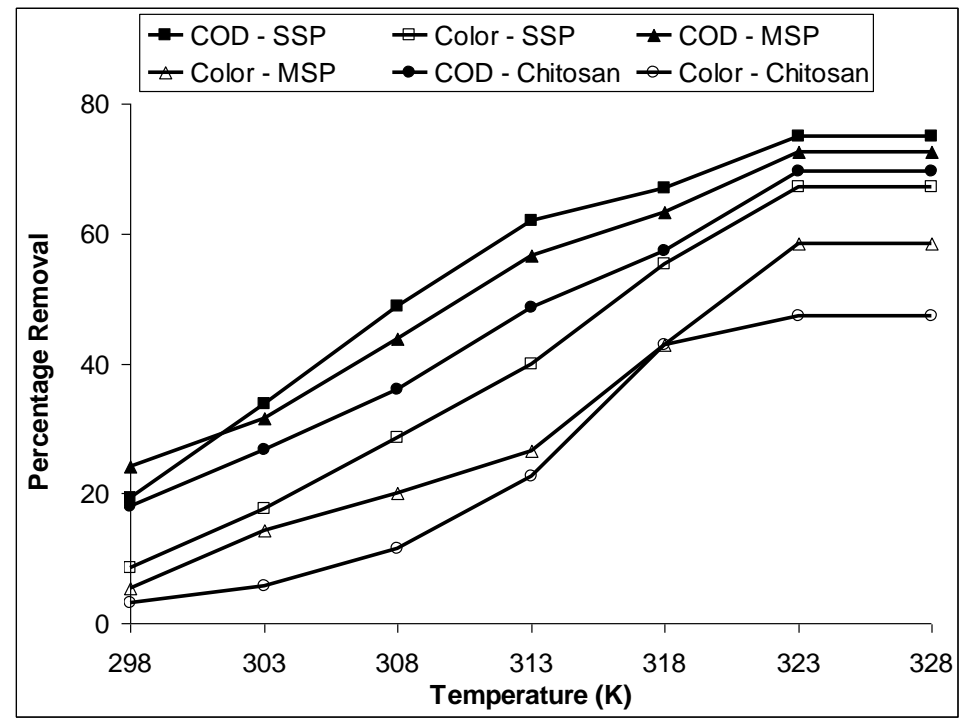

Figure 2. Influence of temperature for removal of COD and color from textile wastewater

\section{Analysis of SVI and Turbidity}

The stability of the microbial aggregates in activated sludge and the effluent quality are crucial in solid-liquid separation processes. Commonly, SVI is the most suitable factor to define the sludge settling ability. The SVI parameter indicates the morphological and settleability state of the microbial aggregates. Sometimes, high numbers of small aggregates and free bacteria, which do not settle, can lead to a high turbidity of the treated effluent. If they are well flocculated, they will become a part of the settling matrix. If not, they will not settle and contribute to higher turbidity. Table 2 mentions the average values of SVI and turbidity using various parameters like coagulant dose, flocculation time and temperature for removal of COD and color from dyeing mill effluent. The decreasing order of SVI was found to be: MSP > SSP > Chitosan. It indicates that lowest SVI are found more desirable by using Chitosan. The average values of SVI for all parameters were found to be 331.2, 402.7 and $402.7 \mathrm{ml} \mathrm{g}^{-1}$ using Chitosan, SSP and MSP, respectively. So, higher values of SVI were found using MSP, than, SSP and Chitosan, respectively. Higher SVI values, which suggest poorer sludge compaction characteristics, were observed for MSP and Chitosan, respectively. So, Chitosan is considered as a significant coagulant than SSP and MSP for all parameters investigated corresponding to SVI values. This phenomenon of Chitosan for SVI could be explained based on charge density. If compared to the other coagulants like SSP and MSP, Chitosan has a high charge density. Moreover, the charge density of the polymer increased when polymer adsorption increased. Therefore, this signifies the rapid destabilization of the particles. In other words, it can be defined as Chitosan, a coagulant which has a high charge density, requires a less amount to destabilize the particles.

The effluent turbidity enhances for all coagulants investigated, despite the SVI decrease, which could be due to several reasons: the inhibition of Wastewater Treatment Plants (WWTPs) regulatory action towards the dispersed bacteria due to the protozoa's decline with salt content increase; and certain species of microorganisms may collapse due to stress leading to the release of their cellular components into the bulk increasing turbidity. With salt concentrations, the higher stress on the microbial cells decreases coagulation and flocculation abilities, which may increase the effluent turbidity. The obtained results for the settleability properties suggested that SVI and turbidity are not directly related. Furthermore, it seems reasonable to assume that both measurements are complementary, and, therefore, turbidity can be a valuable indicator towards the assessment of the aggregated biomass structure (Patel and Vashi, 2012). The average values of turbidity for all factors i.e. coagulant dose, flocculation time and temperature) including process optimization were found to be 359.6, 426.6 and 549.6 NTU using Chitosan, SSP and MSP, respectively. 
Table 2. SVI and turbidity values of investigated parameters for natural coagulants

\begin{tabular}{ccccccc}
\hline \multirow{2}{*}{$\begin{array}{c}\text { Effect of } \\
\text { factors }\end{array}$} & \multicolumn{2}{c}{ Chitosan } & \multicolumn{2}{c}{ SSP } & \multicolumn{2}{c}{ MSP } \\
\cline { 2 - 7 } & $\begin{array}{c}\text { SVI } \\
\left(\mathbf{m l ~ g}^{-1}\right)\end{array}$ & $\begin{array}{c}\text { Turbidity } \\
(\mathbf{N T U})\end{array}$ & $\begin{array}{c}\text { SVI } \\
\left(\mathbf{m l ~ g}^{-1}\right)\end{array}$ & $\begin{array}{c}\text { Turbidity } \\
(\mathbf{N T U})\end{array}$ & $\begin{array}{c}\text { SVI } \\
\left(\mathbf{m l ~ g}^{-1}\right)\end{array}$ & $\begin{array}{c}\text { Turbidity } \\
(\mathbf{N T U})\end{array}$ \\
\hline Coagulant Dose & 312.2 & 325.5 & 425.5 & 400.1 & 541.1 & 512.1 \\
\hline Flocculation time & 326.8 & 365.5 & 384.7 & 412.5 & 587.4 & 548.9 \\
\hline Temperature & 354.5 & 387.8 & 397.8 & 467.3 & 599.9 & 587.8 \\
\hline Average & 331.2 & 359.6 & 402.7 & 426.6 & 576.1 & 549.6 \\
\hline
\end{tabular}

\section{CONCLUSION}

(1) The feasibility for treatment of textile mill wastewater using naturally prepared coagulants viz. SSP, MSP and Chitosan in order for removal of COD and color is analyzed.

(2) The comparative study of these coagulants SSP, MSP and Chitosan are conducted, in which SSP was more preferable than Chitosan and MSP for the removal of COD and color.

(3) The various factors like coagulant dose, flocculation time and temperature were investigated, in which parameter of coagulant dose is found more preferable than other parameters for the removal of COD. Also, parameters of flocculation time is convenient than other parameters investigated for removal of color.

(4) The highest removal of COD (75.6\%) is achieved using parameter, a coagulant dose of SSP $\left(30.0 \mathrm{~g} \mathrm{I} \mathrm{I}^{-1}\right)$ maintaining temperature of $300 \mathrm{~K}$ and flocculation time $60 \mathrm{~min}$. The highest color removal $(62.82 \%)$ is attained using parameter of flocculation time (120 min) maintaining temperature of $300 \mathrm{~K}$ and SSP of $20 \mathrm{~g} \mathrm{l}^{-1}$.

(5) The average maximum SVI and turbidity was found to be $402.7 \mathrm{ml} \mathrm{g}^{-1}$ and $549.6 \mathrm{NTU}$ respectively using MSP and average minimum SVI and turbidity was found to be $331.2 \mathrm{ml} \mathrm{g}^{-1}$ and 359.6 NTU respectively using Chitosan. Therefore, Chitosan was more preferable than SSP and MSP, respectively.

\section{REFERENCES}

Amuda O.S., Amoo I.A., Ajayi O.O. (2006), Performance optimization of coagulant/ flocculant in the treatment of wastewater from a beverage industry, J. Hazard. Mater., 129(1-3), 69-72.

APHA (American Public Health Association) (1992), Standard Methods form the examination of water and wastewater, $18^{\text {th }}$ Edn., Fed. Reg. 44: 27362-27375 Washington, DC.

Beltran-Heredia J. and Martın J.S. (2008), Azo dye removal by Moringa oleifera seed extract coagulation, Color. Technol., 124, 310-317.

Bhatia S., Othman Z. and Ahmad A.L. (2006), Palm oil mill effluent pretreatment using Moringa oleifera seeds as an environmentally friendly coagulant: laboratory and pilot plant studies, J. Chem. Technol. Biot., 81, 1852-1858.

Bhole A.G. (1995), Relative evaluation of a few natural coagulants, J. Water Supply: Res. Technol., 44(6), 284-290.

Bisschops I. and Spanjers H. (2003), Literature review on textile wastewater characterisation, Environ. Technol., 24(11), 1399-1411.

Ebeling J.M., Sibrell P.L., Ogden S.R. and Summerfelt S.T. (2003), Evaluation of chemical coagulation/flocculation aids for the removal of suspended solids and phosphorus from intensive recirculating aquaculture effluent discharge, Aquacult. Eng., 29, 23-42.

Fu Y. and Yu S.L. (2007), Characterization and coagulation performance of solid poly-silicic-ferric (PSF) coagulant, J. Non-Cryst. Solids., 353(22-23), 2206-2213.

Gassenschmidt U., Jany K.D., Tauscher B. and Niebergall H. (1995), Isolation and characterization of a flocculating protein from Moringa oleifera Lam., Biochim. Biophys. Acta, 1243, 477-481.

Gibbs G., Tobin J.M. and Guibal E. (2004), Influence of Chitosan Preprotonation on Reactive Black 5 Sorption Isotherms and Kinetics, Ind. Eng. Chem. Res., 43, 1-11.

Huang C. and Chen Y. (1996), Coagulation of Colloidal Particles in Water by Chitosan, J. Chem. Technol. Biot., 66(3), 221-232.

Jiang J.Q. and Graham N.J.D. (1996), Enhanced coagulation using Al/ Fe(III) coagulants: effect of coagulant chemistry on the removal of colour-causing NOM, Environ. Technol., 17(9), 937-950.

Kobya M., Demirbas E., Can O.T. and Bayramoglu M. (2006), Treatment of levafix orange textile dye solution by electrocoagulation, J. Hazard. Mater., 132(2-3), 183-188. 
Kuai L., De Vreese I., Vandevivere P. and Verstraete W. (1998), GAC-Amended UASB Reactor for the Stable Treatment of Toxic Textile Wastewater, Environ. Technol., 19(11), 1111-1117.

Kwaambwa H.M., Hellsing M. and Rennie A.R. (2010), Adsorption of a Water Treatment Protein from Moringa oleifera Seeds to a Silicon Oxide Surface Studied by Neutron Reflection, Langmuir, 26(6), 3902-3910.

Mandloi M., Chaudhari S. and Folkard G.K. (2004), Evaluation of natural coagulants for direct filtration, Environ. Technol., 25(4), 481-489.

Minamisawa M., Minamisawa H., Yoshida S. and Takai N. (2004), Adsorption Behavior of Heavy Metals on Biomaterials, J. Agric. Food. Chem., 52, 5606-5611.

Muthukumar K., Sundaram P.S., Anantharaman N. and Basha C.A. (2004), Treatment of textile dye wastewater by using an electrochemical bipolar disc stack reactor, J. Chem. Technol. Biot., 79, $1135-1141$.

Ndabigengesere A., Narasiah K.S. and Talbot B.G. (1995), Active agents and mechanism of coagulation of turbid waters using Moringa oleifera, Water Res., 29, 703-710.

Oladoja N.A. and Aliu Y.D. (2008), Evaluation of plantain peelings ash extract as coagulant aid in the coagulation of colloidal particles in low pH aqua system, Water Qual. Res. J. Can., 43(2/3), 231238.

Oladoja N.A. and Aliu Y.D. (2009), Snail shell as coagulant aid in the alum precipitation of malachite green from aqua system, J. Hazard. Mater., 164(2-3), 1496-1502.

Omar F.M., Rahman N.N.N.A. and Ahmad A. (2008), COD reduction in semiconductor wastewater by natural and commercialized coagulants using response surface methodology, Water Air Soil Poll., 195(1-4), 345-352.

Patel H. and Vashi R.T. (2012), Removal of Congo Red dye from its aqueous solution using natural coagulants, J. Saudi Chem. Soc., 16(2), 351-356.

Raghuwanshi P.K., Mandlol M., Shrama A.J., Malviya H.S. and Chudari S. (2002), Improving Filtrate Quality Using Agro based Materials as Coagulant Aid, Water Qual. Res. J. Can., 37, 745-756.

Rahbar M.S., Alipour E. and Sedighi R.E. (2006), Color removal from industrial wastewater with a novel coagulant flocculant formulation, Int. J. Environ. Sci. Technol., 3(1), 79-88.

Ranganathan K., Karunagaran K. and Sharma D.C. (2007), Recycling of wastewaters of textile dyeing industries using advanced treatment technology and cost analysis-Case studies, Resour. Conserv. Recy., 50(3), 306-318.

Rios G., Pazos C. and Coca J. (1998), Destabilization of cutting oil emulsions using inorganic salts as coagulants, Colloid surface. A., 138, 383-389.

Roussy J., Vooren M.V. and Guibal E. (2005), Influence of Chitosan Characteristics on Coagulation and Flocculation of Organic Suspensions, J. Polym. Sci., 98(5), 2070-2079.

Szygla A., Guibal E., Palacin M.A., Ruiz. M. and Sastre A.M. (2009), Removal of an anionic dye (Acid Blue 92) by coagulation-flocculation using chitosan, J. Environ. Manage., 90, 2979-2986.

Vieira A.M.S., Vieira M.F., Silva G.F., Araujo A.A., Fagundes-Klen M.R., Veit M.T. and Bergamasco R. (2010), Use of Moringa oleifera Seed as a Natural Adsorbent for Wastewater Treatment, Water Air Soil Poll., 206(1-4), 273-281. 